\title{
Short-Span Seeking Control of Hard Disk Drive with Vibration Suppression PTC
}

\author{
Keisuke Fukushima Student Member (Yokohama National University) \\ Hiroshi Fujimoto Member (Yokohama National University) \\ Shinsuke Nakagawa Member (Hitachi, Ltd., Shinsuke)
}

Keywords: hard disk drive, multirate control, primary resonance, controllable canonical realization

In a short-span seeking-mode of hard disk drives, the resonance modes are getting crucial obstruction to meet the demand on highspeed data access. At the first generation in a series of research of the authors' research group, we applied perfect tracking control (PTC) to seeking mode with multirate feedforward compensation, in which the plant is modeled as the rigid system with time-delay (rigid PTC). Then, as the second generation, a novel desired trajectory of head position is proposed for the PTC algorithm in order to minimize the residual vibration due to the primary resonance mode (MPVT). However, only the $2^{\text {nd }}$ order rigid mode was considered as nominal model to design the feedforward controller.

In this paper, a novel vibration suppression PTC method is proposed based on controllable canonical realization. In the proposed method, it is assumed that the nominal plant is modeled as the rigid and primary resonance mode. By using this model, the feedforward controller is designed with PTC in order to suppress the primary vibration actively. To apply PTC for the $4^{\text {th }}$ order model, the selection of state variable is extremely important since this algorithm assures perfect tracking of the all state variable at the sampling points of the reference trajectory. Additionally, the higher-order resonance vibration is passively attenuated by using a trajectory named MHVT.

Fig. 1 shows one-track seeking simulation for the nominal model.

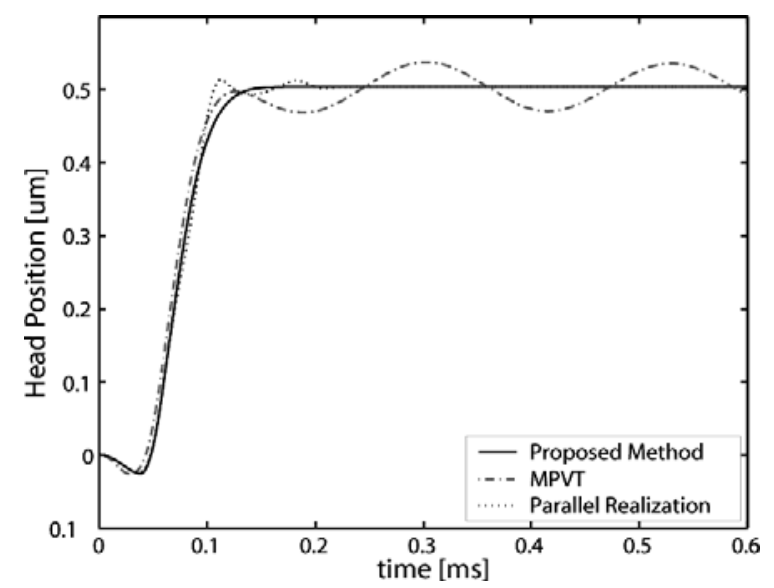

Fig. 1. one-track seeking simulation for the nominal model
We find that proposed method keeps the vibration suppression characteristics, in which MPVT looses the suppression capability. Moreover, the intersample response of the proposed method is much smoother than that of parallel realization.

Fig. 2 shows one-track seeking simulation for the detailed model. Although the rigid PTC excites the mechanical vibration mode, the proposed method suppresses the vibration very well. However, we could not obtain better result than MPVT. The difference between nominal and detailed simulation is caused by the high-order vibration modes. In order to suppress these modes, we use a trajectory named MHVT. Then we find that the proposed method with MHVT has advantage over the other methods in detailed simulation.

Experiments are carried out under the same conditions with detailed simulations. Table 1 shows the average seeking-time is obtained in the experiment. We find that the proposed method acieved $16 \%$ faster seeking than MPVT.

Table 1. Seeking-time

\begin{tabular}{|c|c|c|}
\hline Rigid PTC & MPVT & Proposed method \\
\hline immeasureble & $0.347[\mathrm{~ms}]$ & $0.291[\mathrm{~ms}]$ \\
\hline
\end{tabular}

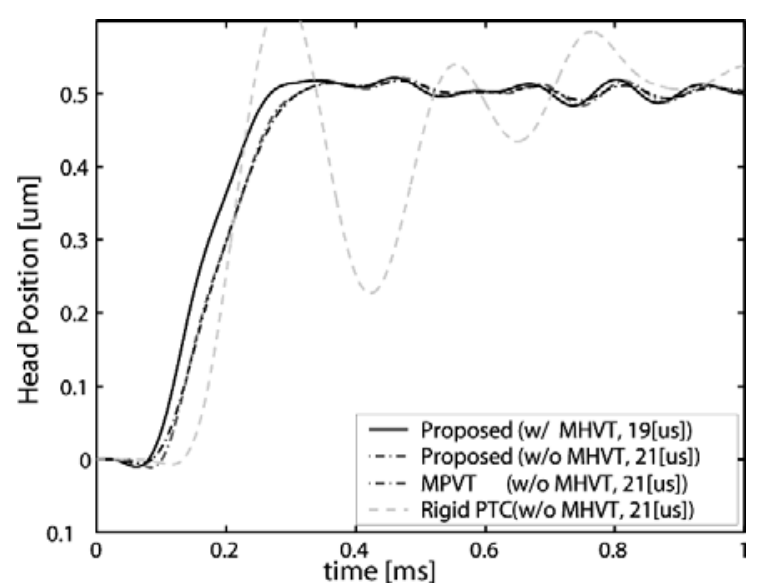

Fig. 2. one-track seeking simulation for the detailed model 


\title{
制振PTCによる磁気ディスク装置のショートスパンシーク制御
}

\author{
学生員 福島 啓介* 正 員 藤本 博志* \\ 正員 中川 真介**
}

\section{Short-Span Seeking Control of Hard Disk Drive with Vibration Suppression PTC}

Keisuke Fukushima*, Student Member, Hiroshi Fujimoto*, Member, Shinsuke Nakagawa**, Member

In a short-span seeking-mode of hard disk drives, the resonance modes are getting crucial obstruction to meet the demand on high-speed data access. In this paper, a novel vibration suppression perfect tracking control (PTC) method is proposed based on controllable canonical realization. In the proposed method, it is assumed that plant is modeled as the rigid and primary resonance mode. By using this model, the feed forward controller is designed with PTC by multirate sampling control in order to suppress the primary vibration. Additionally, the higher-order resonance vibration is attenuated by using a trajectory named MHVT. The proposed method achieved $16 \%$ faster seeking than a conventional called MPVT method.

キーワード：磁気ディスク装置, マルチレート制御, 主共振, 可制御正準実現

Keywords: hard disk drive, multirate control, primary resonance, controllable canonical realization

\section{1. まえがき}

磁気ディスク装置（Hard Disk Drive；HDD）のヘッドを 目標データトラックに位置決めするための動作を大別する と，現在位置から目標トラック近傍までできるだけ高速度 で移動する動作（シーク； seek），目標トラック中心に整定 する動作（セトリング； settling），目標到達後にトラック に高精度で追従する動作（フォロイング；following）に分 類され，各動作モードに対応した制御方式が用意されてい る ${ }^{(1)}$ 。比較的長い距離のシークにおいては, 最大加減速に よるシーク制御系からセトリング制御系へのモード切り替 え制御 ${ }^{(1)}$ が有効である。図 1 に装置の外観図を示す。

これに対し，数トラック程度のショートスパンシークに おいては，制御モードを切り替える必要なしで目標位置に 到達させる 2 自由度制御系が有効とされている(2)。ショー トスパンシーク制御方式において，目標軌道に対する追従 性を向上させるためのフィードフォワード制御信号生成法 として, 零位相誤差追従制御（Zero Phase Error Tracking Control ; ZPETC) ${ }^{(3)}$ に基づく方法や, 完全追従制御（Per-

\footnotetext{
* 横浜国立大学

干 240-8501 横浜市保土ヶ谷区常盤台 79-5

Yokohama National University

79-5, Tokiwadai, Hodogaya-ku, Yokohama 240-8501

** (株) 日立製作所 中央研究所

干 256-8510 小田原市国府津 2880

Hitachi, Ltd., Central Research Laboratory

2-100, Kozu, Odawara 256-8510
}

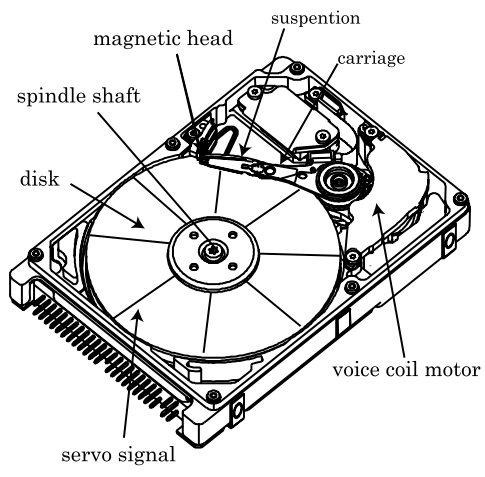

図 1 磁気ディスク装置の外観図

Fig. 1. Hard Disk Drive.

fect Tracking Control ; PTC) (4)(5) に基づく方法が提案され ている。

PTC 法を用いたショートスパンシークにおいて, 著者ら の研究グループの一連の研究における第 1 世代では, 位置 決め機構系において制御対象を剛体モデルとむだ時間で近 似することにより設計していた ${ }^{(5)}$ 。しかし，移動時間の高 速化の要求に伴い, 制御対象に主共振モードを考慮に入れ た設計が必要となった。そこで, 第 2 世代として, 主共振 周波数の加振力増加を防き， 目標位置に追従させるフィー ドフォワード補償の生成法として, 特定振動モード周波数 のパワーを低減する制振軌道を用いる方法 ${ }^{(6)}$ が考えられた。 これは, 目標軌道の共振周波数成分を除去するというある 意味消極的な方法であった。しかし，ノッチフィルタによ 
り共振モードを刺激しないような軌道を与える方法では, 移動時間の高速化に限界がある。

そこで本稿では第 3 世代の PTC 法として, 制御対象モデ ルを剛体モデル+主共振モデルと仮定し, 可制御正準実現に 基づき PTC 法を適用する方法を提案する。提案する $\mathrm{PTC}$ 法を用いることで, 主共振モードを積極的に制御し, サン プル点上で完全追従を達成することが可能である。さらに， 高次の共振振動の影響を低減する目標軌道 (minimizing the higher-order vibration trajectory；MHVT）を与えることで, 目標軌道により高次の振動周波数成分を除去する方法を提 案する。なお，本稿ではショートスパンシークを 1 トラッ クシークとして定義して扱うこととする。

\section{PTC 法 ${ }^{(4)(5)}$}

PTC はマルチレート入力を利用した制御手法で，目標位 置の検出時ごとに制御対象の全状態が目標軌道に完全に誤 差なく追従する完全追従制御系である。全状態変数に対し て目標軌道を与えることを特徽とし，これにより連続的な 制御入力を生成することができると考えられる。また設計 が単純で見通しがよいという長所を持つ。

単入出力 $n$ 次の連続時間制御対象

$$
\dot{\boldsymbol{x}}(t)=\boldsymbol{A}_{c} \boldsymbol{x}(t)+\boldsymbol{b}_{c} u(t), y(t)=\boldsymbol{c}_{c} \boldsymbol{x}(t)
$$

に対して, 図 2 に示すように, 目標軌道のサンプリング周 期 $T_{r}$ の間に制御入力を $n$ 回切り替えるマルチレートサン プリング制御を適用する。短いサンプリング周期 $T_{u}$ で離 散化した制御対象の状態方程式は以下のように定式化でき る(4)。

$$
\boldsymbol{x}[k+1]=\boldsymbol{A}_{s} \boldsymbol{x}[k]+\boldsymbol{b}_{s} \boldsymbol{u}[k]
$$

また，時刻 $t=i T_{r}=k T_{u}$ から $t=(i+1) T_{r}=(k+n) T_{u}$ ま での長いサンプリング周期 $T_{r}$ の状態変数の遷移は以下の ようになる。

$$
\boldsymbol{x}[i+1]=\boldsymbol{A} \boldsymbol{x}[i]+\boldsymbol{B} \boldsymbol{u}[i]
$$

ただし，マルチレート入力ベクトル $\boldsymbol{u}[i]$ の定義は，

$$
\boldsymbol{u}[i]=\left[u_{1}[i], u_{2}[i], \cdots, u_{n}[i]\right]^{T}
$$

とする。また，係数行列は次式で与えられる。

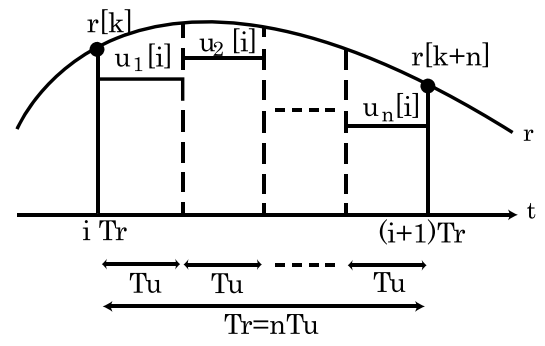

図 2 マルチレートサンプリング制御

Fig. 2. Maltilate sampling control.

$$
\begin{aligned}
& \boldsymbol{A}=\boldsymbol{A}_{s}^{n}, \boldsymbol{B}=\left[\boldsymbol{A}_{s}^{n-1} \boldsymbol{b}_{s}, \boldsymbol{A}_{s}^{n-2} \boldsymbol{b}_{s}, \cdots, \boldsymbol{A}_{s} \boldsymbol{b}_{s}, \boldsymbol{b}_{s}\right] \\
& \boldsymbol{c}=\boldsymbol{c}_{c} \cdots \ldots \ldots \ldots \ldots \ldots \ldots \ldots \ldots \ldots \ldots \ldots \ldots \ldots \ldots \ldots \ldots \ldots \ldots \ldots \ldots \ldots
\end{aligned}
$$

(3) 式で表される制御対象の離散時間状態方程式, および出 力方程式から次式の安定な逆システムが得られる。

$$
\boldsymbol{u}[i]=\boldsymbol{B}^{-1}\left(\boldsymbol{I}-z^{-1} \boldsymbol{A}\right) \boldsymbol{x}[i+1]
$$

従って，次式によりフィードフォワード入力を決定する ことで, ノミナルプラントに対して, サンプル点上での完 全追従 $\left(x[i]=x_{d}[i]\right)$ が補償できる。ただし,$x_{d}$ は状態の 目標軌道である。

$$
\boldsymbol{u}_{f f}[i]=\boldsymbol{B}^{-1}\left(\boldsymbol{I}-z^{-1} \boldsymbol{A}\right) \boldsymbol{x}_{d}[i+1]
$$

外乱やモデル化誤差により追従誤差が生じた場合には，口 バストフィードバック制御器 $C_{2}[z]$ によりその影響をでき るだけ抑圧する。

$$
\boldsymbol{u}[i]=\boldsymbol{u}_{f f}[i]+C_{2}(z)\left(y[i]-y_{0}[i]\right)
$$

\section{3. 制振 PTC 法}

〈3・1〉MPVT を用いた制振 PTC 法 ${ }^{(6)}$ 対象とする特 定振動モード周波数のパワーを低下させる制振軌道（minimizing the primary vibration trajectory；MPVT）を用いた 制振 PTC 法の構成を図 3 に示す。制御系の特長は以下の 通りである。

図中ブロック 1 では剛体モデルを仮定したときのPTC 法 により加速度フィードフォワード補償を生成しており, 制 御対象を 2 重積分系 $\left(1 / s^{2}\right)$ と仮定している。

図中ブロック 2 ではMPVTを用いた目標位置軌道・目標 速度軌道を生成しており, MPVTを与えることにより目標 軌道自身の加振成分を抑制している。(9) 式に位置の目標值 応答を決定する規範伝達関数モデルを示す。分子に帯域除 去特性を指定している。また，速度の目標值応答を決定す る規範伝達関数モデルは (9) 式を 1 階微分したものとする。

$$
G_{m}(s)=\frac{s^{2}+2 \zeta_{r} \omega_{r} s+\omega_{r}^{2}}{\omega_{r}^{2} \prod_{i=1}^{n}\left(\tau_{i} s+1\right)}
$$

ここで, $\tau_{i}$; 応答の時定数, $\omega_{r}$; 主共振周波数, $\zeta_{r}$; 主共振 周波数の減衰係数を示す。この軌道から PTC 法により得ら れる加速度 FF 制御入力は特定周波数成分のパワーを低く できることから，シーク時に主共振周波数の振動を抑制す

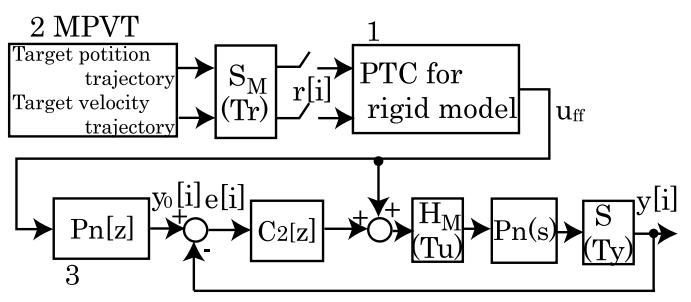

図 3 MPVT を用いた制振 PTC 法の構成 Fig. 3. Vibration suppression PTC by MPVT. 
ることができる。

図中ブロック 3 では制御対象モデルを剛体モデル+共振 モデルとして仮定することで軌道追従誤差を低減し，目標 位置軌道補正が沶こなわれる。与える加速度フィードフォ ワード制御入力から，(10) 式で表される主共振を考慮した 制御対象モデルを用いてフィードバック制御用の目標位置 軌道を再計算し，軌道追従誤差を抑制する。

$$
P_{n}(s)=K_{p}\left(\frac{1}{s^{2}}+\frac{a_{r}}{s^{2}+2 \zeta_{r} \omega_{r} s+\omega_{r}^{2}}\right)
$$

$\langle\mathbf{3} \cdot \mathbf{2}\rangle$ 並列接続実現による制振 PTC 法 MPVT を 用いた制振 PTC 法では，フィードフォワード制御系を剛体 モデルのみに対して PTC 法により設計し，別に主共振によ る加振成分を抑圧する方法であったが，以下では剛体モデ ル+主共振モデルで表される制御対象モデルに対して PTC 法によりフィードフォワード補償を実現し，目標位置に正 確に追従させる方法を考える。

まず，物理的直感から容易に構成できる剛体モデルと主 共振モデルの並列接続実現による制振 PTC 法について述べ る。図 4 に構成を示す。これは，剛体モデルと主共振モデ ルに対してそれぞれ 2 次の PTC 法を設計し，並列に接続す る。これにより設計される 4 次の PTC 法に扔いて, 状態 变数 $\boldsymbol{x}$ に対しては， $x_{1} ， x_{2}$ に剛体モデルに対する目標位置 軌道・目標速度軌道を， $x_{3} ， x_{4}$ に主共振モデルに対する目 標位置軌道・目標速度軌道を与えることができる。このと き，係数行列 $\boldsymbol{A}_{c}, \boldsymbol{b}_{c}, \boldsymbol{c}_{c}$ は以下のように定まる。

$$
\begin{aligned}
\boldsymbol{A}_{c} & =\left[\begin{array}{cccc}
0 & 1 & 0 & 0 \\
0 & 0 & 0 & 0 \\
0 & 0 & 0 & 1 \\
0 & 0 & -\omega_{r}^{2} & -2 \zeta_{r} \omega_{r}
\end{array}\right], \boldsymbol{b}_{c}=\left[\begin{array}{c}
0 \\
K_{p} \\
0 \\
K_{p} a_{r}
\end{array}\right] \ldots \ldots \\
\boldsymbol{c}_{c} & =\left[\begin{array}{llll}
1 & 0 & 1 & 0
\end{array}\right] \ldots \ldots \ldots \ldots \ldots \ldots \ldots \ldots
\end{aligned}
$$

目標軌道は，剛体モデルと共振モデルのそれぞれに与え る割合 $a, b$ を $a+b=1$ の条件の下で変化させ, 目標軌道 を実現するものとする。

$\langle\mathbf{3} \cdot \mathbf{3}\rangle$ 可制御正準実現による制振 PTC 法（提案法）

次に，(10) 式の対象モデルを以下のように変形したも のを考える。

$$
P_{n}(s)=K_{p} \frac{\left(1+a_{r}\right) s^{2}+2 \zeta_{r} \omega_{r} s+\omega_{r}^{2}}{s^{4}+2 \zeta_{r} \omega_{r} s^{3}+\omega_{r}^{2} s^{2}}
$$

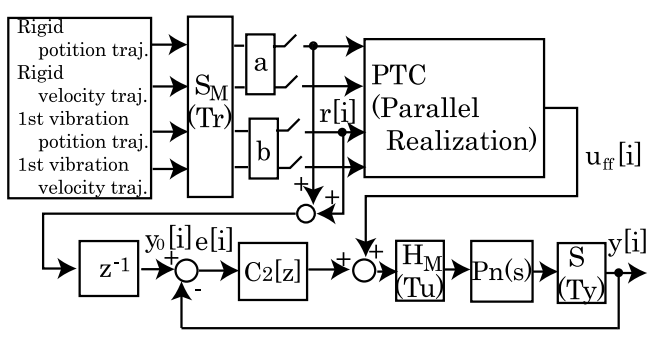

図 4 並列接続実現による制振 PTC 法の構成

Fig. 4. Vibration suppression PTC by parallel realization.
このような高次系に対しての PTC 法の設計は，文献(4) で可制御正準形とすべきであることが述べられている。こ れは, 制御対象の出力変数だけではなく全状態変数に目標 軌道を与え，これに完全に追従させることにより，連続的 な制御入力と滑らかなサンプル点間応答を実現させるため である。また，文献(7) では，この考え方をロボットの多 自由度マニピュレータに適用している。

提案法の構成を図 5 に示す。また，(13) 式を可制御正準 形により 4 次の PTC 法を実現すると, 係数行列 $\boldsymbol{A}_{c}, \boldsymbol{b}_{c}, \boldsymbol{c}_{c}$ は以下のように定まる。

$$
\begin{aligned}
& \boldsymbol{A}_{c}=\left[\begin{array}{cccc}
0 & 1 & 0 & 0 \\
0 & 0 & 1 & 0 \\
0 & 0 & 0 & 1 \\
0 & 0 & -\omega_{r}^{2} & -2 \zeta_{r} \omega_{r}
\end{array}\right], \boldsymbol{b}_{c}=\left[\begin{array}{c}
0 \\
0 \\
0 \\
K_{p} \omega_{r}^{2}
\end{array}\right] \ldots \ldots \\
& \boldsymbol{c}_{c}=\left[\begin{array}{llll}
1 & \frac{2 \zeta_{r}}{\omega_{r}} & \frac{1+a_{r}}{\omega_{r}^{2}} & 0
\end{array}\right] \ldots \ldots \ldots \ldots \ldots \ldots
\end{aligned}
$$

ここで指令值の与え方を述べる。PTC 法においては状態 変数 $\boldsymbol{x}(t)$ に対して目標軌道を与えるため, $x_{1}(t)=z(t)$ とお くと,

$$
\boldsymbol{x}_{d}(t)=\left[z_{d}(t), z_{d}^{(1)}(t), z_{d}^{(2)}(t), z_{d}^{(3)}(t)\right]^{T}
$$

と与えることができる。ただし $z_{d}$ は $z$ に与える軌道であ $\eta, z_{d}^{(n)}$ は $z_{d}$ の $n$ 階微分である。上式より,(13) 式で表さ れる剛体モデル+主共振モデルの状態変数 $\boldsymbol{x}$ において, $z_{1}$ に位置の次元を与えたとき $z_{2} \cdot z_{3} \cdot z_{4}$ にそれぞれ速度・加 速度・加加速度の次元まで与えることが可能であり, これ により滑らかなサンプル点間応答が実現できる(4)。しかし ながら,$y(t) \neq x_{1}(t)$ であるため, $z$ はへッド位置ではない

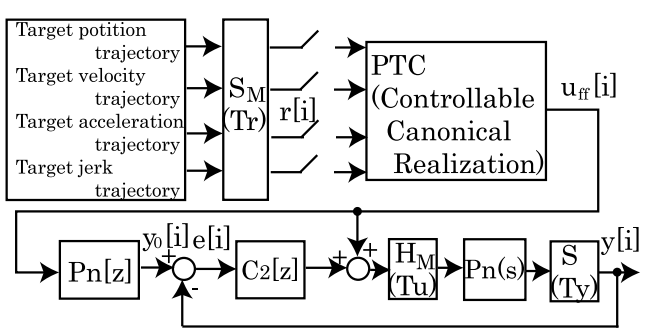

図 5 可制御正準実現による制振 PTC 法の構成

Fig. 5. Vibration suppression PTC by proposed method.

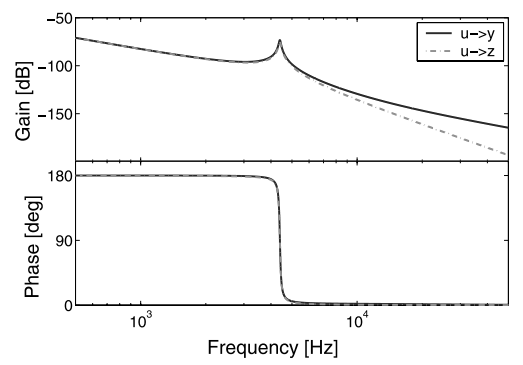

図 6 制御対象モデルの周波数応答

Fig. 6. Frequency response of Plant. 
ことに注意されたい。その物理的意味を明らかにするため に $u$ から $z$ までの伝達関数を計算すると, 以下の式で表さ れる。

$$
\frac{z}{u}=K_{p} \frac{\omega_{r}^{2}}{s^{4}+2 \zeta_{r} \omega_{r} s^{3}+\omega_{r}^{2} s^{2}}
$$

このとき， $u$ から $y$ までの伝達関数と, $u$ から $z$ までの 伝達関数との周波数応答を確認すると, 図 6 に示すように, 低域においては特性がほぼ一致している。これは通常の可 制御正準形とは異なり，(15) 式のように第 1 成分を 1 にな るように規格化しているためである。したがって， $z$ は位 置の次元 $([\mathrm{m}])$ を持つものとして考えることができ，これ を仮想位置と定義する。つまり $z$ は厳密にはヘッド位置を 意味しているのではなく，仮想位置に目標位置軌道を与え これに対して完全追従させている。

\section{4. シミュレーション}

〈4・1〉ノミナルモデルに対するシミュレーション 3 章で述べた制振 PTC 法を用いて，(10) 式のノミナルモデル に対して 1 トラックシークのシミュレーションを行なう。 目標值である 1 トラックピッチは，0.504 [ $\mu m]$ である。ま た, $\omega_{r}=2 \pi 4400[\mathrm{rad} / \mathrm{sec}], \zeta_{r}=0.01, a_{r}=-1.2, K_{p}=277$ とした。

ここで，制御周期とサンプリング周期の関係を表 1 に示 す。本制御系においては, 目標軌道と出力のサンプリング 周期 $\left(T_{r}, T_{y}\right)$ と, 制御周期 $\left(T_{u}\right)$ を異なる值に設定されてい ることに注意されたい。これは，PTCに対する制御対象モ デルが [剛体] のときと [剛体+共振] のときでは, 入力多重 度が 2 と 4 で異なるので, $T_{u}$ を等しくして比較するためで ある。また，目標軌道は $(\tau s+1)^{-8}$ のステップ応答とする。 ただし $\tau$ は応答の時定数である。

表 1 制御周期とサンプリング周期の関係

Table 1. Control period and sampling period.

\begin{tabular}{c||c|c|c}
\hline Plant model for PTC & $T_{r}$ & $T_{u}$ & $T_{y}$ \\
\hline Rigid & $38.4[\mu s]$ & $19.2[\mu s]$ & $38.4[\mu s]$ \\
Rigid + Resonances & $76.7[\mu s]$ & $19.2[\mu s]$ & $38.4[\mu s]$ \\
\hline
\end{tabular}
(MPVT は上段，並列接続実現・提案法は下段)
MPVTを用いた制振 PTC 法についてのシミュレーショ ン結果を図 7(a) に示す。シーク時間を短くしすぎると制振 効果が得られなくなることが確認できる。

並列接続実現による制振 PTC 法についてのシミュレー ション結果を図 7(b) に示す。剛体モデル, 共振モデルに与 える軌道の割合 $a, b$ を変化させ, 比較すると, それぞれサ ンプル点上では目標位置軌道に追従しているものの, 共振 モデルに目標位置軌道を与えると共振モデルの影響が顕著 に現れてしまう。

可制御正準実現による制振 PTC 法についてのシミュレー ション結果を図 7(c) に示す。MPVT では制振効果が得ら れないシーク速度に対しても制振効果が得られていること が確認できる。また，剛体モデルにのみ目標軌道を与えた 並列接続実現による制振 PTC 法と比較したとき, より滑ら かなサンプル点間応答を達成できていることが図 8 からも 確認できる。これは, 並列接続実現による方法ではサンプ ル点上で無理矢理共振モードの位置と速度を 0 にするのに 対し，可制御正準実現による方法では前述したように，目 標軌道を位置 · 速度 · 加速度 · 加加速度に対して滑らかに 与え，これに完全に追従させているためである(4)。

〈4・2〉 詳細モデルに対するシミュレーション

〈4・2・1〉＼cjkstart詳細モデルについて＼cjkstart本シミュレーションに おいて評価する磁気デイスク装置 $(3.5$ インチ・10,000 rpm) の制御対象モデルを図 9 のブロック図に示す。ノミナルシ ミュレーションでは主共振までを考慮していたが，実際の 磁気ディスク装置はVCM からなる駆動部とアクセス機構 からなり, アクセス機構は次のような伝達関数 $P_{a}(\mathrm{~s})$ で表 される。

$$
P_{a}(s)=K_{p}\left(\frac{1}{s^{2}}+\sum_{i=1}^{l} \frac{a_{i}}{s^{2}+2 \zeta_{i} \omega_{i} s+\omega_{i}^{2}}\right) \cdots \cdots
$$

ここで, $m$; ヘッド位置換算質量, $\zeta_{i} ; i$ 次モードの減衰係 数, $\omega_{i} ; i$ 次モードの固有振動数, $a_{i}$; ゲインを示す。第 1 項は剛体モード, 第 2 項は複数の振動モードからなる共振 モデルである。今回は 4 次共振モード $(l=4)$ までを考慮 し，周波数応答を図 10 の実線に示す。

またこの磁気ディスク装置の制御対象モデルに対して,

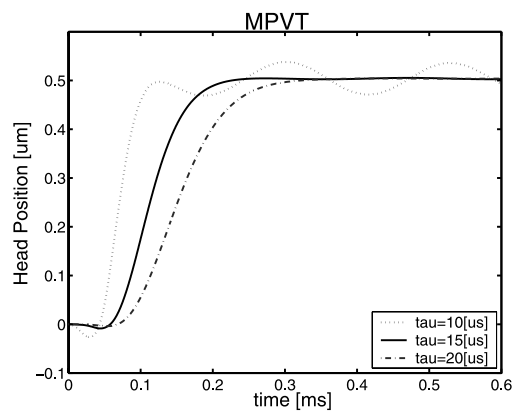

(a) MPVT

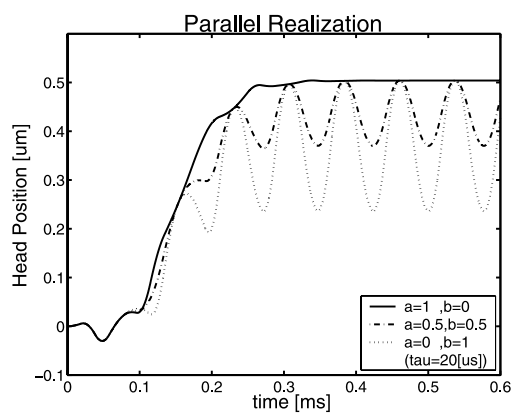

(b) Parallel Realization

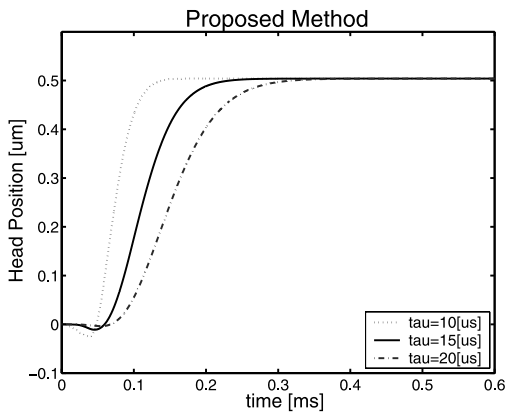

(c) Proposed Method

図 7 ノミナルモデルに対するシミュレーション

Fig. 7. Simulation for nominal model. 


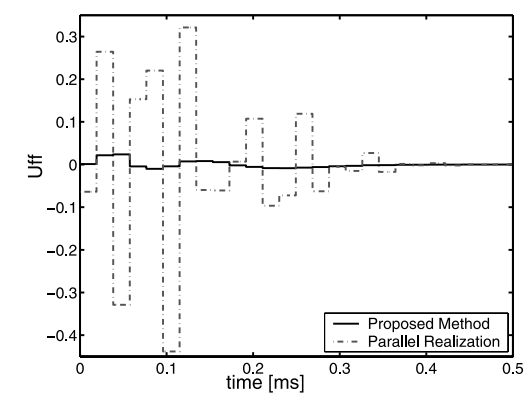

図 8 制御入力の比較 $(\tau=10[\mu \mathrm{s}])$

Fig. 8. Control input $(\tau=10[\mu \mathrm{s}])$.

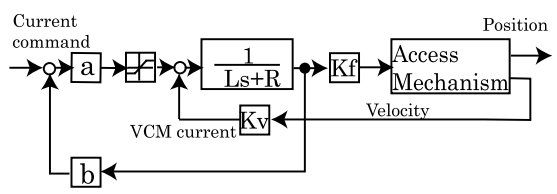

困 9 磁気ディスク装置の詳細モデル

Fig. 9. Detailed model of HDD.

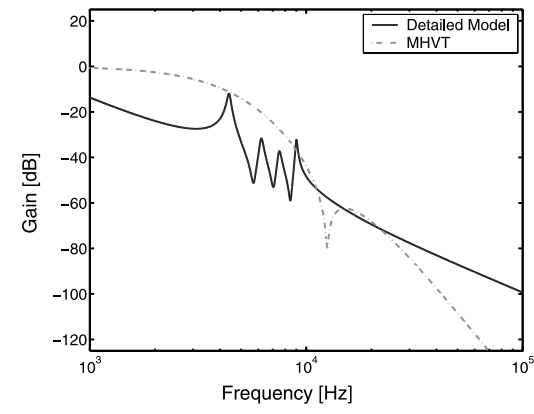

図 10 詳細モデルと MHVT の周波数応答

Fig. 10. Frequency response of detailed model and MHVT.

モデル誤差要因子として演算時間遅れとパワーアンプの位 相遅れが存在する。今回はこれらのモデル誤差要因を等価 時間遅れ $e^{-L s}(L=20[\mu \mathrm{s}])$ とし, 以下を $T_{y}$ 毎に計算して いる。

$$
\begin{aligned}
& P_{n}[z]=Z\left[\frac{1-e^{-T_{y} s}}{s} e^{-L s} P_{n}(s)\right] \ldots \ldots \ldots \ldots \ldots \ldots \\
& y_{0}[k]=P_{n}(z) u_{f f}[k] \ldots \ldots \ldots \ldots \ldots \ldots \ldots \ldots \ldots
\end{aligned}
$$

$\langle\mathbf{4} \cdot \mathbf{2} \cdot \mathbf{2}\rangle$ 詳細シミュレーション 提案法に加えて, 共 振モードを全く考慮しない剛体モデルに対する PTC 法（剛 体 PTC) と, MPVT に対して詳細シミュレーションを行なっ た。なお，磁気デイスク装置においては，過渡応答が大き すぎると，デー夕を読み書きする動作が正確に行なえない。 そこで今回は，設計条件として過渡応答は 1 トラックピッ チ $(=0.504[\mu \mathrm{s}])$ の $\pm 5 \%$ 以内とし，設計条件を満たす範囲 内で試行錯誤的に $\tau$ の值を最小化させ，シミュレーション を行なった。結果を図 11 に示す。このとき， $\tau=21[\mu \mathrm{s}]$ を 得た。剛体 PTCでは主共振により振動が励起されているの に対して，制振 PTC 法を用いることで制振効果が得られて いることが明確である。しかし，MPVT と提案法を比較し

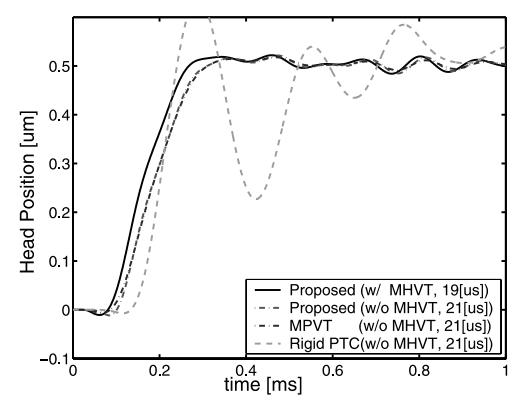

図 11 詳細シミュレーション

Fig. 11. Simulation for detailed model.

た場合，明確な差は得らず，図 11 中で 2 手法は重なってい ることに注意されたい。

この理由は, 設計条件の下で最小化して得られた $\tau=21[\mu \mathrm{s}]$ の場合をノミナルシミュレーションで比較すると明らかで ある。ノミナルシミュレーションにおいて，2手法の差が顕 著になるのは $\tau=10[\mu \mathrm{s}]$ 付近であることが図 7 より分かる。 しかしながら詳細シミュレーションにおいては $\tau=21[\mu \mathrm{s}]$ までしか最小化できない。 $\tau=21[\mu \mathrm{s}]$ では 2 手法とも主共 振モードの影響は抑圧可能である。詳細シミュレーション において, 差が顕著になる $\tau$ の值まで最小化できない理由 は，高次共振モードの影響である。

そこで，目標軌道として MHVTを与える。文献 (6) では, 剛体モードを PTC 法により積極的に制御し，ノッチフィル 夕により主共振モードにおける目標軌道の周波数成分を落 としていた。提案する制振 PTC 法では剛体モード+主共振 モードを積極的に制御しているため, 主共振モードは目標 軌道の带域に含め, 高次共振モードの周波数成分を MHVT により除去する。MHVT の規範伝達関数モデルは以下のと おりである。

$$
G_{h}(s)=\frac{s^{2}+2 \zeta_{h} \omega_{h} s+\omega_{h}^{2}}{\omega_{h}^{2} \prod_{i=1}^{n}\left(\tau_{i} s+1\right)} .
$$

ここで, $\tau_{i}$; 応答の時定数, $\omega_{h}$; 高次周波数, $\zeta_{r}$; 指定し た高次周波数の減衰係数を示す。MHVTを用いることで, 2 次共振モード以降の $\omega_{h}$ の付近で帯域除去特性を与える ことが可能である。詳細モデルと MHVT のゲイン特性を 図 10 に示すが，図から見てとれるように，MHVTで指定 する高次周波数は必ずしも詳細モデルの高次共振周波数と は一致する必要はないことに注意されたい。これは，目標 軌道の周波数帯域を上げたい要求と, 高次共振モード付近 でゲインを落としたい要求とがトレードオフの関係である ためである。そこで試行錯誤的にゲインを落としたい高次 周波数 $\omega_{h}$ を求めたところ, 本稿の詳細シミュレーション では $\omega_{h}=11.5[\mathrm{kHz}]$ と定めた。

図 11 に示されるように，MHVTを用いたときは，設計 条件を満たすように $\tau$ の值を最小化させたところ $\tau=19[\mu \mathrm{s}]$ まで実現可能である。したがって，高次共振モードの影響 を抑圧することで，より高速なシークが可能である。 


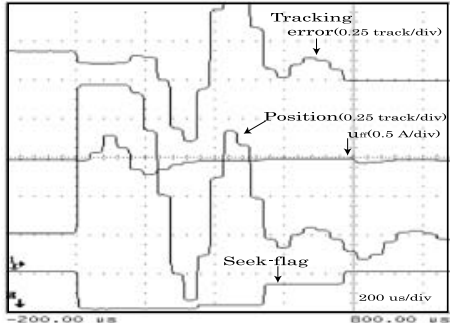

(a) Rigid PTC

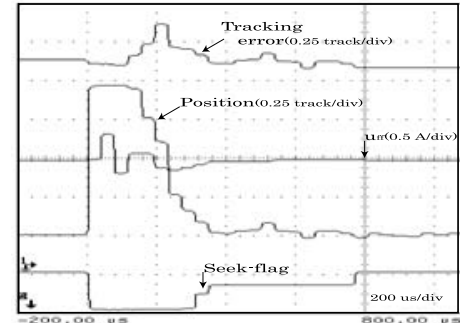

(b) MPVT

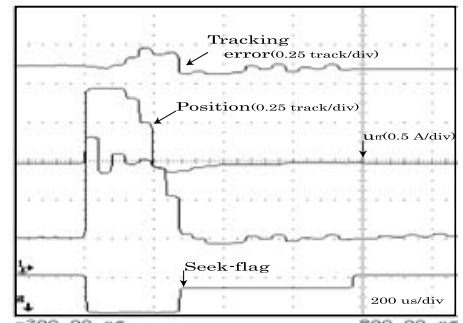

(c) Proposed Method (w/MHVT)

図 12 実験結果 (平均波形)

Fig. 12. Experimental result (averaged wave form).

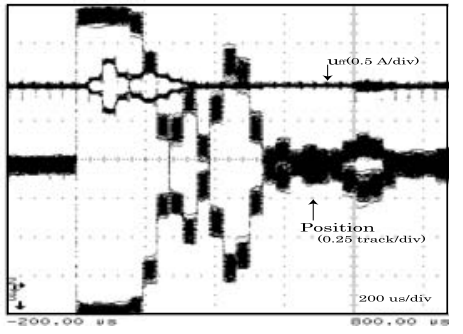

(a) Rigid PTC

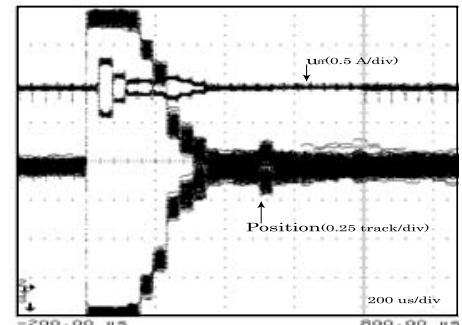

(b) MPVT

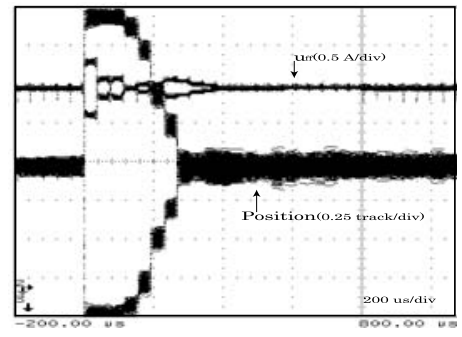

(c) Proposed Method (w/MHVT)

図 13 実験結果（露光波形）

Fig. 13. Experimental result (envelope).

表 2 シーク時間

Table 2. Seeking-time.

\begin{tabular}{|c|c|c|}
\hline Rigid PTC & MPVT & Proposed Method \\
\hline imeasureable & $0.347[\mathrm{~ms}]$ & $0.291[\mathrm{~ms}]$ \\
\hline
\end{tabular}

\section{5. 実験結果}

詳細モデルに対して行なったシミュレーションを実験に より確認する。実験装置は 3.5 インチ・10,000 rpm の HDD を用いた。前節と同様に，比較対象は剛体 PTC と MPVT とする。実験結果として，平均波形（128 回）を図 12 に, 露光波形（1000 回）を図 13 にそれぞれ示す。なお, 装置 の都合上，位置誤差信号を同周期で更新されるように表示 しているが，実際はマルチレート入力を与えていることに 注意されたい。詳細シミュレーション同様, 剛体 PTCで は主共振により振動が励起されているのに対して，本提案 法を用いることで制振効果が得られていることが明らかと なった。

また，シーク時間を表 2 に示す。ここで，シーク時間を 1 トラックの $10 \%$ 帯へ最終的に到達した時間と定義するこ とにするが，剛体 PTC に関しては幾度も $10 \%$ 帯に出入り しており，シーク時間は測定不能であった。高次の帯域除 去特性を持たせないMPVT に対して, 約 16\%の高速化が 実現できた。

\section{6. おわりに}

本稿では, HDDのショートスパンシークにおいて，高速 化の弊害となっている主共振モードに対して，可制御正準 実現による制振 PTC 法を提案した。以前から提案されて
いた主共振周波数に帯域除去特性を持たせる MPVTによ る制振 PTC 法に対して，ノミナルシミュレーションにおい て, MPVTですら振動が励起されるシーク時間に対しても, 本提案法を用いることで制振効果が得られることが明確と なった。また, 詳細シミュレーションにおいて, 高次共振 モードに帯域除去特性を持たせる目標軌道を用いることで シークの高速化が可能であることが明らかになった。共振 モードの影響を抑圧したい場合，軌道の共振周波数成分を 除去するという, ある意味消極的な手法よりも，共振モー ドを PTC 法に基づき積極的に制御する提案法の有効性が明 らかとなった。

(平成 17 年 6 月 24 日受付, 平成 17 年 12 月 1 日再受付)

\section{文献}

(1) T. Yamaguchi, K. Shishida, S. Tohyama, and H. Hirai: "Mode Switching Control Design with Initial Value Compensation and Its Application to Head Positioning Control on Magnetic Disk Drives", T. SICE, Vol. 31, No.6, pp.780-788 (1995-6) (in Japanese)

山口高司 - 宾田和久. 遠山聡一・平井洋武：「モード切り換え型制御 系の初期值補償設計と磁気ディスク装置ヘッド位置決め制御サーボ 系への適用」, 計測自動制御学会論文集, 31, 6, pp.780-788 (1995-6)

(2) S. Takakura: "Design of the Tracking System using N-Delay Two-Degreeof-Freedom Control and its Application to Hard Disk Drives", T. IEE Japan, Vol.119-D, No.5, pp.728-734 (1999-5) (in Japanese) 高倉晋司：「N-Delay2 自由度制御による目標値追従システムの構成 と磁気ディスク装置への応用」, 電学論 D, 119, 5, pp.728-734 (1999-5)

(3) M. Tomizuka: "Zero Phase Error Tracking Algorithm for Digital Control", Trans. ASME, J. of Dynamic Syst., Measurement, and Control, Vol.109, pp.65-68 (1987-3)

(4) H. Fujimoto, Y. Hori, and A. Kawamura: "Perfect Tracking Control Mehod Based on Multirate Feedforward Control", T. SICE, Vol.36, No.9, pp.766772 (2000-9) (in Japanese)

藤本博志・堀 洋一・河村篤男 : 「マルチレートフィードフォワー ド制御を用いた完全追従制御法」, 計測自動制御学会論文集, 36, 9, pp.766-772 (2000-9) 
(5) H. Fujimoto, Y. Hori, T. Yamaguchi, and S. Nakagawa: "Seekig Control of Hard Disk Drive by Perfect Tracking using Multirate Sampling Control", T. IEE Japan, Vol.120-D, No.10, pp.1157-1164 (2000-10) (in Japanese)

藤本博志・堀 洋一・山口高司・中川真介：「マルチレートサンプ リングを用いた完全追従制御法による磁気ディスク装置のシーク制 御」, 電学論 D, 120, 10, pp.1157-1164 (2000-10)

(6) S. Nakagawa, T. Yamaguchi, H. Fujimoto, Y. Hori, K. Ito, and Y. Hata "Multi-rate Two-Degree-of-Freedom Control for Fast and Vibration-less Seeking of Hard Disk Drives", Proc. ACC, pp.2797-2802, Arlington, America (2001-6)

( 7 ) Y. Shinohara and A. Shimada: "Motion Control on Low Stiffness Manipulators using Multi-Rate Sampling Control", IEE of Japan Technical Meeting Record, IIC-05-65, pp.43-46 (2005-3) (in Japanese)

篠原優介・島田 明：「マルチレートサンプリング制御による低剛性 マニピュレータ制御」, 電気学会産業計測制御研資, IIC-05-65, pp.43-46 (2005-3)

島 啓 介（学生員） 1982 年生。 2005 年 3 月 横浜国立大学

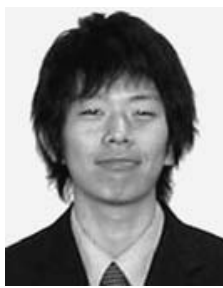
工学部電気電子情報工学科卒業。同年 4 月同大学 大学院工学府物理情報工学専攻に進学。磁気ディ スク装置のヘッド位置決め制御に関する研究に 従事。

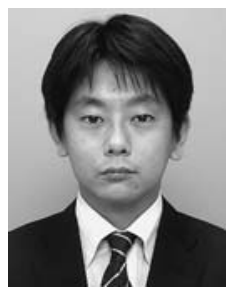

（正員） 1974 年 2 月 3 日生。 2001 年東京大学大 学院工学系研究科電気工学専攻博士課程修了。工 学博士。同年長岡技術科学大学工学部電気系助手。 2002 年 8 月より 1 年間, 米国 Purdue 大学工学部 機械工学科客員研究員。2004 年 4 月横浜国立大 学大学院工学研究院講師。2005 年 4 月同助教授。 制御工学, モーションコントロール, マルチレー 卜制御に関する研究に従事。2001 年 IEEE Trans. IE 最優秀論文賞等受賞。計測自動制御学会, 日本ロボット学会, IEEE 各会員。

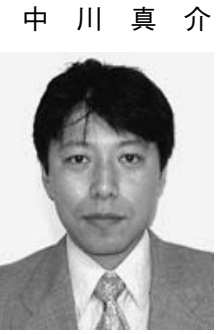

（正員） 1966 年生。1989 年 3 月慶応義塾大学機 械工学科卒業。1991 年 3 月同大学大学院理工学 研究科機械工学専攻修了。工学博士。同年（株） 日立製作所機械研究所入社。現在，（株）日立製 作所中央研究所に勤務。磁気ディスク装置位置決 めサーボ系の研究開発に従事。日本機械学会, 計 測自動制御学会各会員。 